\title{
Genesis of iron-apatite ores in Posht-e-Badam Block (Central Iran) using REE geochemistry
}

\author{
Mir Ali Asghar Mokhtari ${ }^{1, *}$, Ghader Hossein Zadeh ${ }^{2}$ \\ and Mohamad Hashem Emami ${ }^{3}$ \\ ${ }^{1}$ Faculty of Science, University of Zanjan, Zanjan, Islamic Republic of Iran. \\ ${ }^{2}$ Faculty of Science, University of Tabriz, Tabriz, Iran. \\ ${ }^{3}$ Geoscience Research Centre, Geological Survey of Iran, Tehran, Iran. \\ ${ }^{*}$ Corresponding author. e-mail: amokhtari@znu.ac.ir
}

Rare earth elements in apatites of different ore types show characteristic patterns which are related to different modes of formation of the ores. Most of the apatite-bearing iron ores are associated with alkaline magmas with LREE/HREE fractionation varying from moderate to steep.

Iron-apatite deposits in Posht-e-Badam Block (Central Iran) have a high concentration of REE (more than $1000 \mathrm{ppm}$ up to 2.5\%), and show a strong LREE/HREE ratio with a pronounced negative Eu anomaly. This REE pattern is typical of magmatic apatite and quiet distinct from sedimentary apatites (phosphorites) which have a low REE contents and Ce negative anomalies. On the other hand, they are comparable to the REE patterns of apatites in Kiruna-type iron ores in different parts of the world.

The REE patterns of apatites, iron-apatite ores and iron ores are similar and only have different REE contents. This similarity indicates a genetic relation for these rocks. Most of the iron-apatite deposits in Central Iran have similar REE patterns too, which in turn show a genetic relation for all of these deposits. This similarity indicates a similar origin and processes in their genesis. There are some small intrusions around some of the iron-apatite deposits that are petrographically identified as syenite and gabbro. These intrusions also have REE patterns similar to that of iron-apatite ores. This demonstrates a genetic relation between these intrusions and iron-apatite ores.

The REE patterns of apatites in different deposits of Posht-e-Badam Block iron-apatite ores show an affinity to alkaline to sub-alkaline magmas and rifting environment. The alkaline host rocks of Central Iran iron-apatite ores are clearly related to an extensional setting where rifting was important (SSE-NNW fault lines). A probable source for this large scale ore forming processes is relatively low partial melting of mantle rocks. The ores have originated by magmatic differentiation as a late phase in the volcanic cycle forming sub-surface injections or surface flows. These ores have formed during magmatism as immiscible liquids (silicate and Fe-P-rich magmatic liquids) which separated from strongly differentiated magmas aided by a large volatile and alkali element content. Separation of an iron oxide melt and the ensuing hydrothermal processes dominated by alkali metasomatism were both involved to different degrees in the formation of Posht-e-Badam Block iron-apatite deposits. We proposed that the separation of an iron oxide melt and the ensuing hydrothermal processes dominated by alkali metasomatism were both involved to different degrees in the formation of Posht-e-Badam Block iron-apatite deposits.

Keywords. Central Iran; iron-apatite ore; Kiruna-type; Posht-e-Badam Block; REE geochemistry. 


\section{Introduction}

Magnetite-apatite ore deposits can be classified into two major groups:

- high-Ti, apatite-rich (commonly 30\% apatite), magnetite-ilmenite deposits (nelsonites) associated with anorthosites; and

- low-Ti, magnetite deposits with variable amounts of apatite (Kiruna type ores) principally associated with volcanic rocks.

The origin of the first type is generally accepted to be magmatic, with liquid immiscibility between silicate magma and iron-titanium-phosphorous-oxide magma, small percent partial melting of Fe and P-rich crustal rocks, or extreme crystal fractionation the most commonly cited processes (Philpotts 1967; Kolker 1982; Barton and Johnson 1996; Naslund et al. 2000). The origin of the second type, however, is a subject of controversy.

The Kiruna-type ores are the most important. They have attracted a wide genetic interest but, one of the most important genetic models is that they are considered as magmatic (segregation) deposits (Frietsch and Perdahl 1995). The magmatic genesis based on field observations is supported by the geochemical features of the main components of the ores. More recent studies of Kiruna-type ores (Broman et al. 1999; Naslund et al. 2000; Bergman et al. 2001) suggest that they are likely to have been deposited from a Fe-oxide melt that was rich in volatiles and $\mathrm{P}$, followed by separation of water-rich fluids and extensive hydrothermal overprint.

The REE content of igneous minerals is controlled by the mineral-melt distribution coefficients and REE patterns depend on the bulk REE composition of the parent magma (Taylor and McLennan 1985). Of crucial importance is the similarity between the REE patterns in apatite, magnetite and the igneous host rock, pointing to consanguinity between them. For example, in the Skaergaard gabbro, the apatite, pyroxene, ilmenite and magnetite have REE patterns similar to each other and similar to that of the host rock (Paster et al. 1974).

Apatites show a relatively wide range of chemical variations depending on the environment in which they have formed. Fluorine, chlorine, hydroxyl and carbonate mutually replace each other. Apatites contain REE in small amounts replacing $\mathrm{Ca}^{2+}$ and play an important role for the REE distribution in ores and rocks (Hughes et al. 1991). Apatites from iron ores of the Posht-e-Badam Block are commonly fluor-apatite (Borumandi 1973; Darvish Zadeh 1982). A similar feature is observed in the apatites from Kiruna-type ores (Parak 1985). This feature is typical for the igneous apatites such as those from the Skeargaard intrusion, which show high F/Cl ratios (Brown and Peckett 1977).

The origin of the Posht-e-Badam Block magnetite-apatite deposits is a subject of longstanding debate and remains controversial. Different ore genesis models have been proposed for these ore deposits.

Most of the early authors proposed a metamorphic origin for the Posht-e-Badam Block Fe-apatite deposits, although some geologists who mainly worked on the NISCO projects (1971, 1974, 1975, 1979a, b, 1980) proposed a metasomatic origin involving metamorphism, volcanic and intrusive activity.

Williams and Houshmand Zadeh (1966) proposed a magmatic origin for the Choghart deposit and compared it with the Kiruna Fe ore deposits. Investigators supporting an immiscible liquid magmatic model of formation included Förster and Borumandi (1971) and Förster and Jafarzadeh (1984) who reported magnetite lava flows, sills, dykes and magnetite-bearing pyroclastic rocks at Chador Malu and suggested a carbonatitic affinity for the Fe-oxide melt (a theme amplified in the account of the Posht-e-Badam Block magnetiteapatite deposits by Förster and Jafarzadeh 1984). Förster and Jafarzadeh (1994) considered that magmatic materials in the Posht-e-Badam Block to be the product of differentiation and liquid immiscibility of a mela-nephelinitic melt. Jafarzadeh (1981) interpreted the Chador Malu deposit as an explosive vent filled with magnetite melt. Samani (1988) classified mineralization at the Choghart mine and at anomalies 20 and 26, as being of magnetite-carbonatite type.

Darvish Zadeh (1982) and Darvish Zadeh and Al-e-Taha (1996) investigated the mineralogical and geochemical characteristics of the Esfordi $\mathrm{Fe}-\mathrm{P}$ deposit. Based on the mineralogical association of magnetite, apatite and carbonate it was concluded that there was a relationship between carbonatitic magmatism and mineralization, although no in-situ carbonatites were found at Esfordi.

Haghipour and Pelissier (1977a, b) wrote a geological and petrological report on the stratigraphic correlation of the Posht-e-Badam Block host rocks. He had previously suggested a close relationship between $\mathrm{Fe}$ ore deposits and metasomatic metamorphism in some deposits but a volcanogenic or syngenetic origin in other deposits (Haghipour 1964). Similarly, Momen Zadeh (1978, 1982, 1986) proposed a syngenetic submarine volcanogenic origin for Posht-e-Badam Block deposits based on their massive, lenticular, banded and lens-like morphology, their development within a specific lithostratigraphic unit and relation to nearby stratified Mn and Pb deposits. Daliran (1990, 1999, 2002) 
also concluded that hydrothermal fluids played a prominent role in the evolution of the Bafa magnetite-apatite deposits.

Moore and Modaberi (2003) suggested that the separation of an iron oxide melt and the ensuing hydrothermal processes dominated by alkali metasomatism were both involved to different degrees in the formation of Choghart and other similar deposits in Central Iran.

Jami (2005) believed that the Esfordi Fe-P mineralized system displays substantial similarities with other Kiruna-type Fe-oxide deposits worldwide. He proposed that the Esfordi deposit was formed in an evolving hydrothermal system, in a shallow marine volcanic setting, with fluids involved from diverse sources, rather than the deposit being the direct result of quenching of a Fe-oxide + P-rich magmatic melt.

Based on oxygen isotope studies in Chador Malu deposit, Shamsi Pour et al. (2008) proposed that magnetite has a magmatic origin, and hematite was formed by martitization of magnetite.

Torab (2010) proposed an extent hydrothermal system for the Posht-e-Badam Block iron-apatite ores based on geochemistry of apatite, REE and $\mathrm{Sm}-\mathrm{Nd}$ isotopes.

Bonyadi et al. (2010) considered that SeChahoun iron-apatite deposit to be an example of a Kiruna-type deposit. Based on their EMPA analysis on apatite crystals, this deposit was evolved by the hydrothermal processes.

Stosch et al. (2011) have done some U-Pb ages on the apatites from the iron oxide deposits of Posht-e-Badam Block and concluded that they have been formed 539 and 527 Ma. Obtained apatite ages fall entirely within the age range of the felsic magmatic rocks dated by Ramazani and Tucker (2003) [525-547 Ma]. This confirms field evidence that the ore formation was closely related to the Early Cambrian magmatic event (Daliran 2002).

As mentioned above, iron-apatite ores of Poshte-Badam Block are considered as Kiruna-type deposit. None of these studies didn't consider the REE geochemistry of the iron-apatite deposits and alkaline intrusion near them. This paper presents an investigation on the geochemistry of REE in the iron-apatite ores and syenitic and gabbroic intrusions in the Posht-e-Badam Block (Central Iran) and their genetic relation.

\section{Geology}

The Posht-e-Badam Block is a narrow N-S trending rift zone which is part of the Central Iranian Structural Zone (Stöcklin 1968) situated in its eastern part, west of the Lut Block (figure 1).
Rifting took place in the late Precambrian and is characterized by sequences of non-metamorphic volcanic and volcano-sedimentary rocks, local evaporates, bimodal volcanism, large subvolcanic rhyolitic masses, syenite and later diabase. Iron ore deposits, apatite-bearing magmatic rocks which are known as apatites (Daliran 1999), Pb-Zn ores and Th-U mineralization are related to this riftogenic event (Daliran 1990; Samani 1993).

The Posht-e-Badam Block is a metallogenic/ tectonic province of Infracambrian age, with the most important iron ore resources of Iran located between Bafq city in the south and Posht-e-Badam village in the north (figures 1 and 2). This block is located between the western Yazd Block and the Central Tabas Block that, together with the Lut Block further to the east, constitute the crustal domain of the Central Iranian Terrain. The Poshte-Badam Block comprises a basement of Neoproterozoic metamorphic rocks, Early Cambrian diorites to tonalites and an unmetamorphosed Early Cambrian volcano-sedimentary unit with minor evaporites (CVSU, Ramazani and Tucker 2003) and individual volcanic rocks. The volcanism has a predominantly felsic character (rhyolitic to rhyodacitic) with subordinate amounts of andesites and is associated with spilitic basalts, rare undersaturated volcanic rocks of nephelinitic to basanitic composition, small mafic intrusive bodies and late diabase dike swarms, both with alkalic character (Ramazani and Tucker 2003). The Early Cambrian magmatism has been related to an arc setting by Ramazani and Tucker (2003) whereas the predominantly bimodal volcanism and its alkalic character led Samani (1998), Daliran (2002) and Daliran et al. $(2009,2010)$ to favour an extensional episode during or shortly after arc volcanism. On the latest Neoproterozoic to Early Cambrian metamorphic basement (550540 Ma; Ramazani and Tucker 2003), an Early Cambrian magmatic arc developed. A granodiorite cropping out approximately $10 \mathrm{~km}$ NW of Zarigan - of the granite-tonalite suite gave a $\mathrm{U}-\mathrm{Pb}$ zircon age at $533 \pm 1 \mathrm{Ma}$; a dacite-porphyry from Chahgaz and a rhyodacite $\sim 25 \mathrm{~km}$ north of Chahgaz each gave a U-Pb zircon age of $528 \pm$ 1 Ma (Ramazani and Tucker 2003). In the Zarigan area, the rhyolites are intruded by $525 \pm 7$ and $529 \pm 16$ Ma old shallow-level leucogranites of the 'Narigan-Zarigan type'. The CVSU is unconformably overlain by the Lower Cambrian ZaigunLalun Formation and the Middle Cambrian trilobite-bearing Mila Formations (Förster and Jafarzadeh 1994).

The Posht-e-Badam Block constitutes the most significant Fe-oxide and phosphate deposits in the world. It contains reserves of over 2 billion tonnes of Fe (NISCO 1980) within more than 34 major 


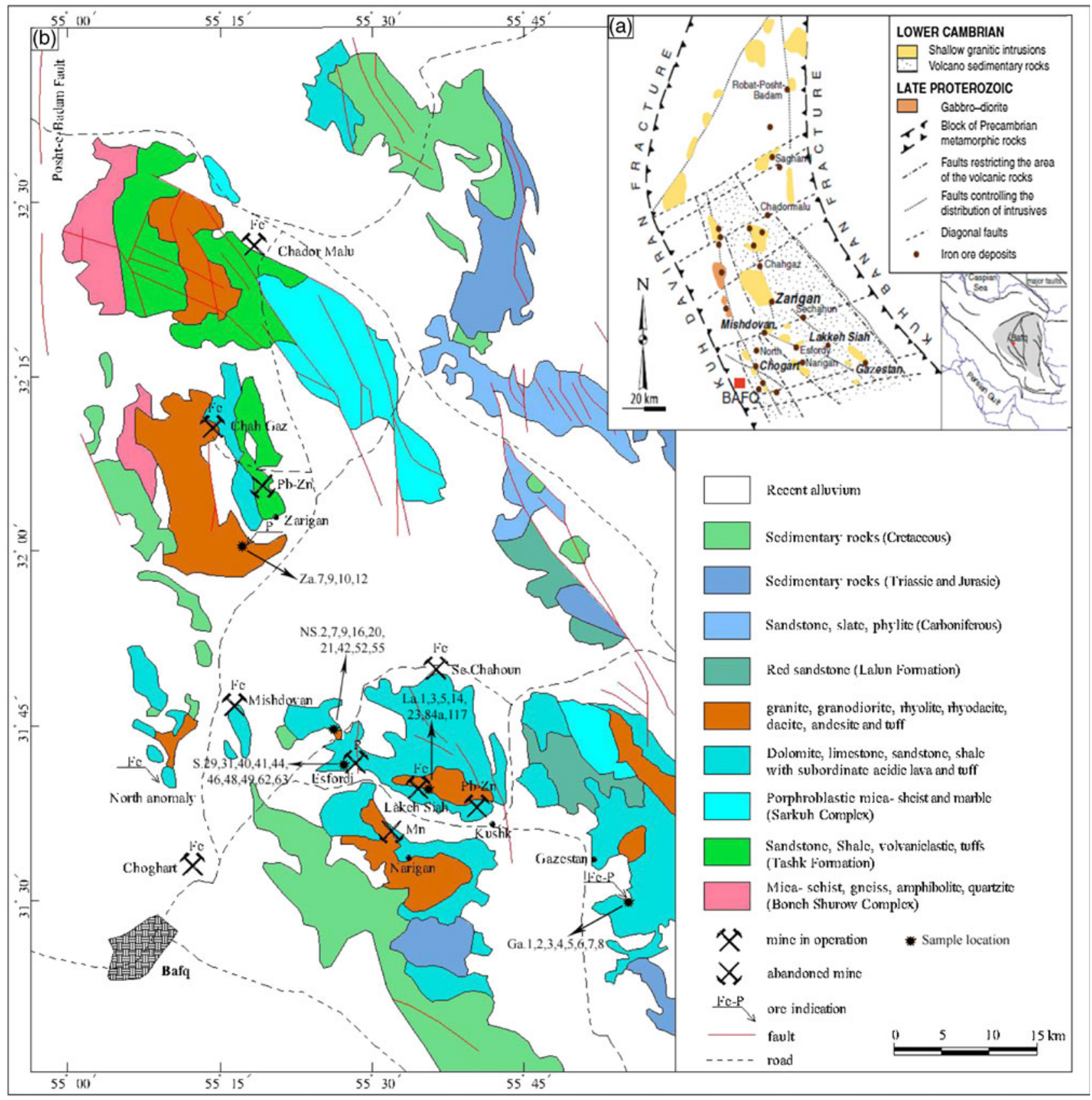

Figure 1. (a) Structural scheme of the Posht-e-Badam Metallogenic Block is limited by crustal meridional faults (modified after NISCO 1980). (b) Simple geological map of southern part of Posht-e-Badam Block based on Haghipour (1977a) showing the location of the iron-apatite deposits in this area.

magnetic anomalies in a $7500 \mathrm{~km}^{2}$ area. Among these targets, 14 have been defined as major deposits with over 1 billion tonnes of high grade ore (53-65\% Fe) (Taghizadeh 1976). The most economic iron ores consist of magnetite with apatite (such as, at Choghart, Chador Malu, Esfordi, Zarigan, Lakeh Siah, Gazestan, Se-Chahoun, Mishdovan, etc.) (figures 1 and 2). SSE-NNW fault lines were important for tectonic evolution of these ores (Daliran 1990).
The ore bodies of Posht-e-Badam Block are hosted by a lower Cambrian volcano-sedimentary sequence (also known as Saghand Formation) composed of lavas, pyroclastic, epiclesis rocks, intercalated carbonates, associated with number of mafic and felsic intrusions (Jami 2005; Torab 2010). Volcanic rocks are rhyolite and rhyodacite in composition and the sedimentary rocks are mainly dolomite. These ore bodies are commonly associated with pervasively altered rhyolitic tuffs and 


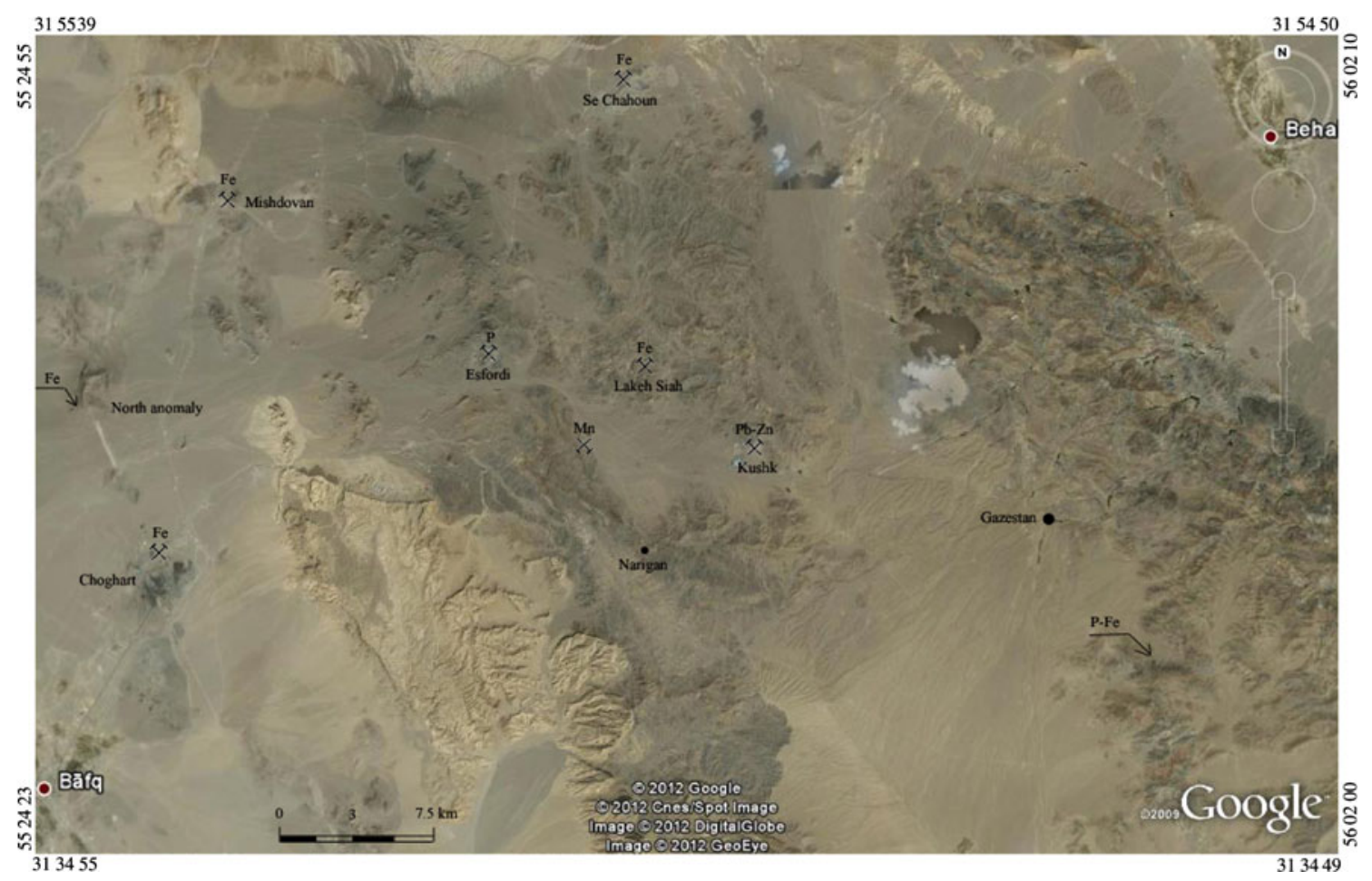

Figure 2. Location of the iron-apatite deposits in the southern part of the Posht-e-Badam Block (Bafq region) on the satellite image.

sandstones. Some iron-apatite ores of this block are associated with green rocks (Daliran 1990; Samani 1993). These rocks probably are the result of alteration in K-feldspars rich intrusions (Daliran 1990). In addition to magnetite-apatite ores, there are several non-ferrous ore bodies containing $\mathrm{Pb}-\mathrm{Zn}$, $\mathrm{Mn}$ and $\mathrm{U}$ (figures 1 and 2).

Pebbles of iron-oxide ore were found in the basal Cambrian conglomerate of the Mila Formation in the area of Zarigan (Haghipour 1975), indicating that mineralization preceded the deposition of these Lower to Middle Cambrian conglomerates.

Iron-apatite ores of Posht-e-Badam Block composed of magnetite ( \pm hematite \pm martite), magnetite-apatite and apatite. In most of these deposits (e.g., Gazestan, Esfordi, Zarigan and Lakeh Siah), euhedral apatite crystals were present in the magnetite or green rocks matrix with porphyroidic texture (figure 3). Also, in some deposits (e.g., Esfordi), concentration of fine grain apatite crystals formed phosphatic zones within and around the iron ore body and green rocks.

All analyzed apatite samples from the Posht-eBadam Block are fluorine-rich and rather low in chlorine (Stosch et al. 2011); this is common for apatite from felsic to intermediate (as well as other) magmatic rocks and independent of their relation to ore systems (Piccoli and Candela 2002).

REE mineralization in the Posht-e-Badam Block is related to the iron-apatite deposits (Darvish
Zadeh 1982; Abedian 1983; Samani and Babakhani 1990; Daliran 1990; Samani 1998, 1999; Kryvdik and Mykhaylov 2001; Rahmani and Mokhtari 2002; Jami 2005; Torab 2010). Enrichment in REE is one of the specialities of the iron-apatite ores in this region. These elements are concentrated mainly in apatite crystals, but other minerals such as monazite, xenotime, bastnasite, urtite, thorite and bertholite have been recognized that are rich in REE (Kryvdik and Mykhaylov 2001; Jami 2005; Torab 2010). These minerals are secondary and present as small inclusions within the apatite, carbonate and hematite-carbonate (as monazite) and quartz veins and veinlets (as urtite) (Kryvdik and Mykhaylov 2001; Jami 2005; Torab 2010).

\section{Research method}

Our research includes two parts: field work and laboratory investigations. Field work includes sampling from the iron-apatite ores and syenitic and gabbroic intrusions in the Posht-e-Badam Block (Central Iran) for analyzing REEs. In the course of the laboratory work, 25 whole-rock samples and apatite crystals separated from iron-apatite deposits were analyzed for REE and other rare elements by ICP-MS (table 1). The analyses were made in ALS Chemex Laboratory in Canada. 

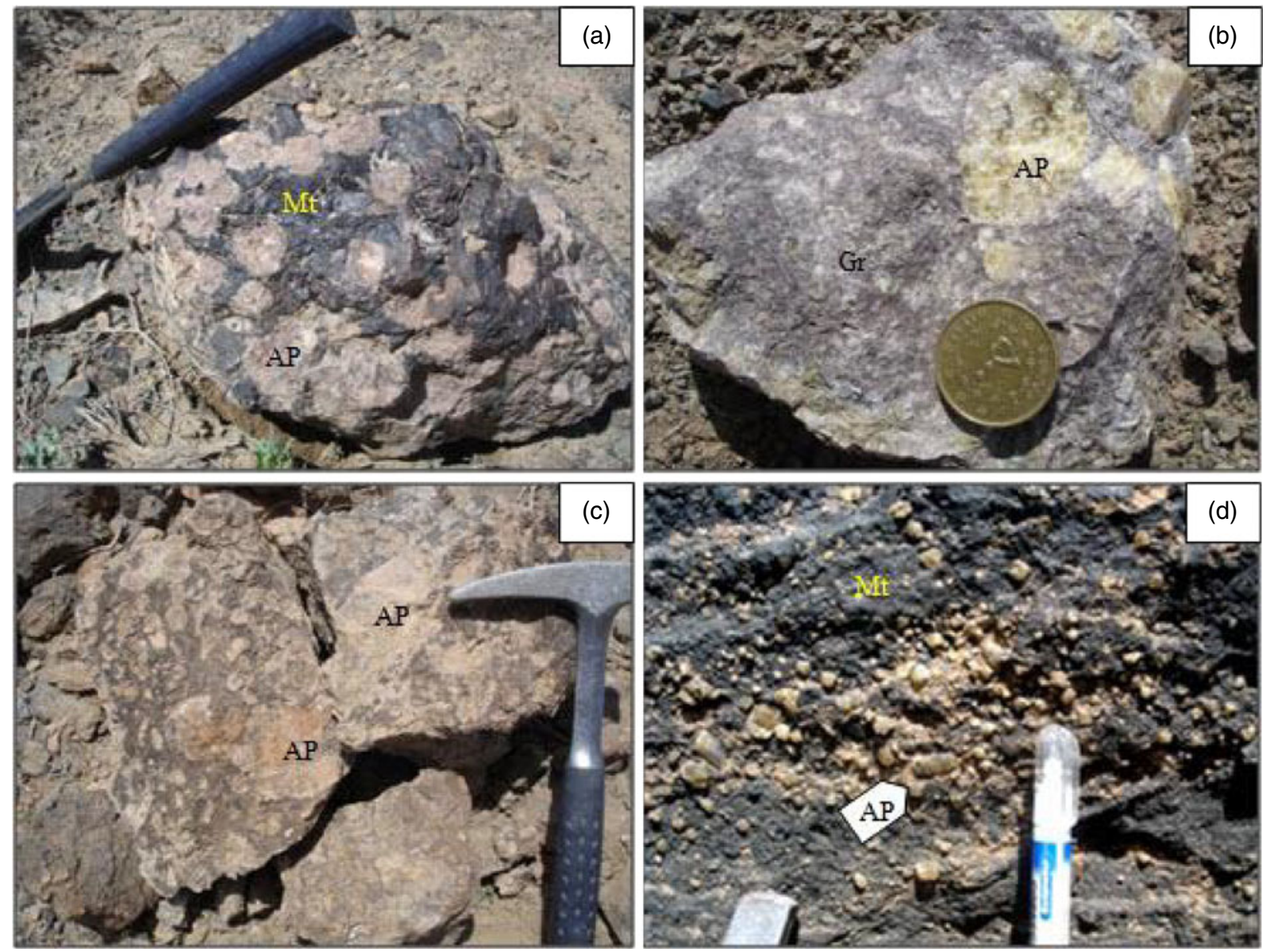

Figure 3. Coarse-grained euhedral apatite crystals within (a) the magnetite ore at the Gazestan deposit, (b) the green rocks at the Esfordi deposit, (c) the Zarigan phosphate deposit and (d) fine to coarse-grained euhedral apatite crystals within the magnetite at the Lakeh-Siah deposit.

The detection limits for analyzing these elements were shown in table 1.

\section{Geochemistry}

Apatites from iron-apatite ores of Posht-e-Badam Block (e.g., Esfordi, Gazestan, Zarigan and Lakeh Siah) have a high concentration of REE (1000 ppm up to 2.5\%) (Rahmani and Mokhtari 2002; Jami 2005; Mokhtari and Emami 2008; Torab 2010; Stosch et al. 2011), and show a common pattern, a strong LREE/HREE fractionation and negative $\mathrm{Eu}$ anomaly (figure 4). Strong LREE/HREE fractionation is a common characteristic of magmatic apatites connected with alkaline rocks. Eu depletion indicates that parent magma has undergone feldspar crystal fractionation.

According to Taylor and McLennan (1985), REE distribution patterns depend on the bulk REE composition in the parent magma. Most of the apatite-bearing iron ores are associated with alkaline to sub-alkaline magmas with a LREE/HREE fractionation varying from moderate to steep
(Frietsch and Perdahl 1995). REE patterns in iron-apatite ores of Posht-e-Badam Block are similar to that of Kiruna in Sweden (figure 5; Frietsch and Perdahl 1995; Harlov et al. 2002), Avnik in Turkey (Helvaci 1984; Aral 1986), El Laco in Chile (Frutos et al. 1990), Abovjan in Russia (Frietsch and Perdahl 1995) and Iron Spring in USA (Frietsch and Perdahl 1995). All the above iron ores have a magmatic origin.

Some authors such as Parak (1975) considered that the apatites of Kiruna-type iron ores to be sedimentary. However, the REE content and patterns show that the apatites of Kiruna-type ores are different from sedimentary apatites. The content of REE in the apatites of Kiruna iron ores is about 2000-7000 ppm (Frietsch and Perdahl 1995) and in the apatites of Central Iran iron ores is more than $1 \%$ (up to 2.5\%) (Rahmani and Mokhtari 2002; Mokhtari and Emami 2008), whereas the content of REE in apatites from phosphorites is less than $1000 \mathrm{ppm}$ and show a Ce depletion (figure 6). Ce deficiency, characterizing marine apatites is not seen in igneous apatites (Laajoki 1975; Altschuler 1980). 


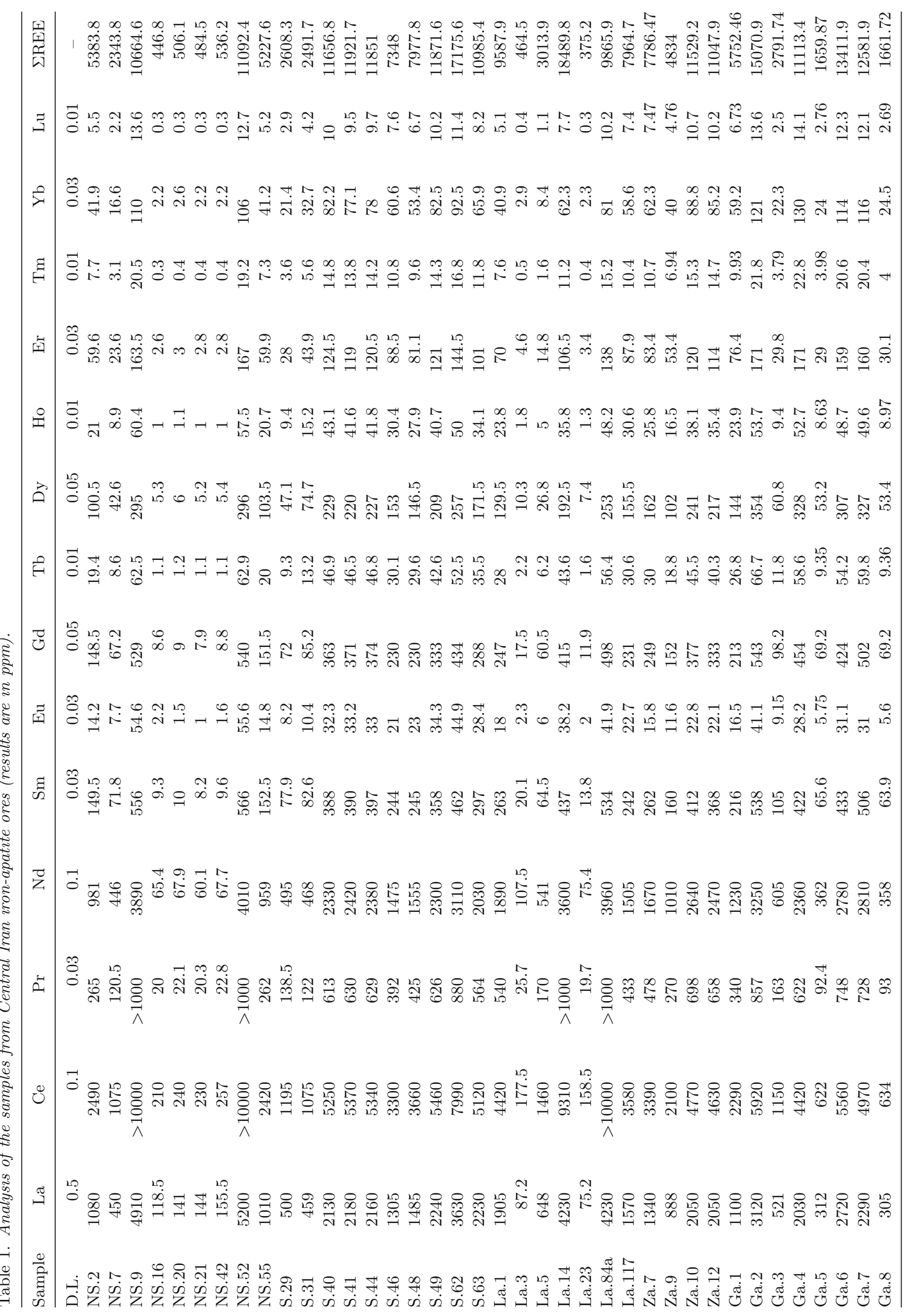



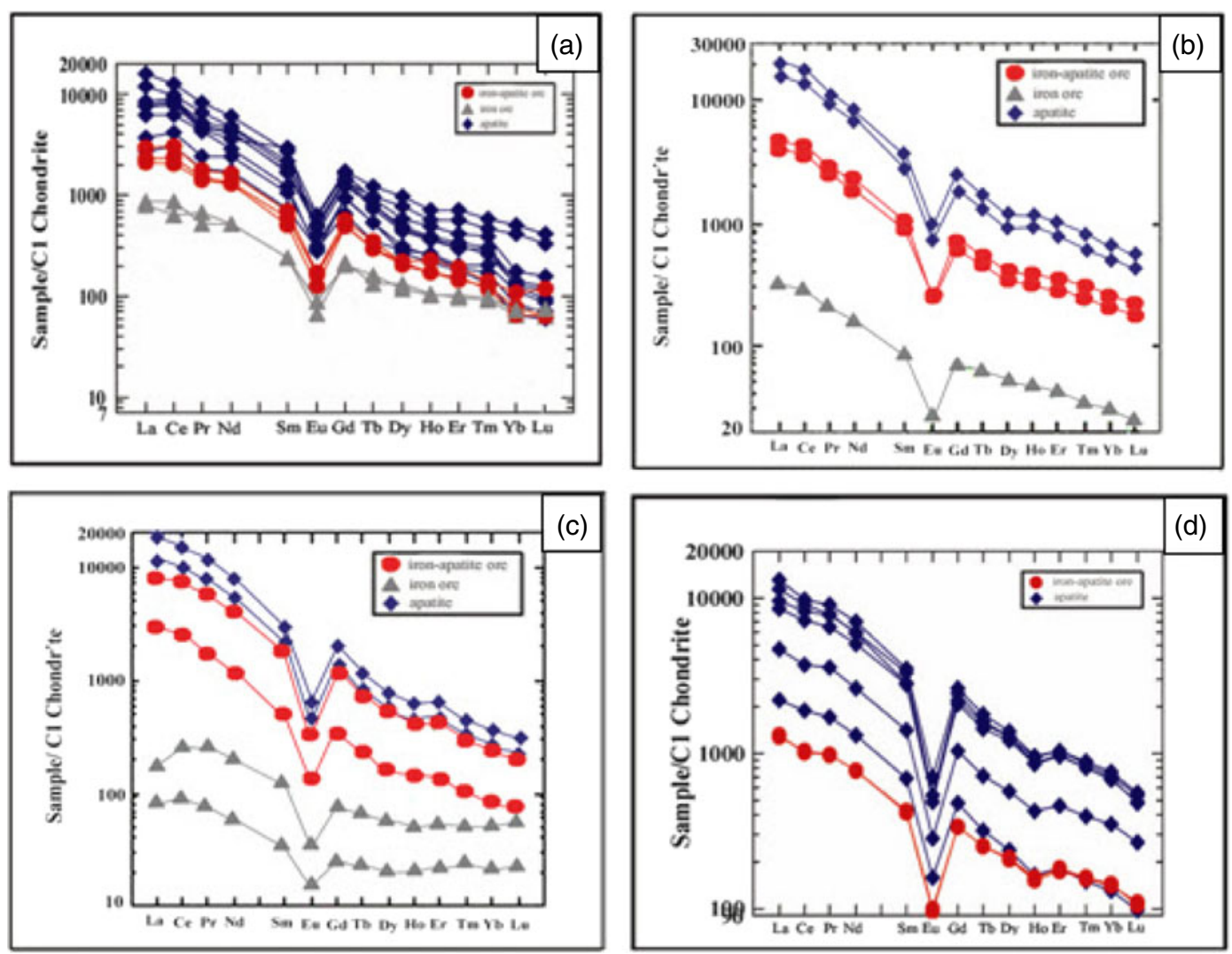

Figure 4. Chondrite-normalized REE pattern for apatites, apatite-bearing iron ores and iron ores from Posht-e-Badam Block iron-apatite ores (a: Esfordi, b: North Esfordi, c: Lakeh Siah, d: Gazestan).

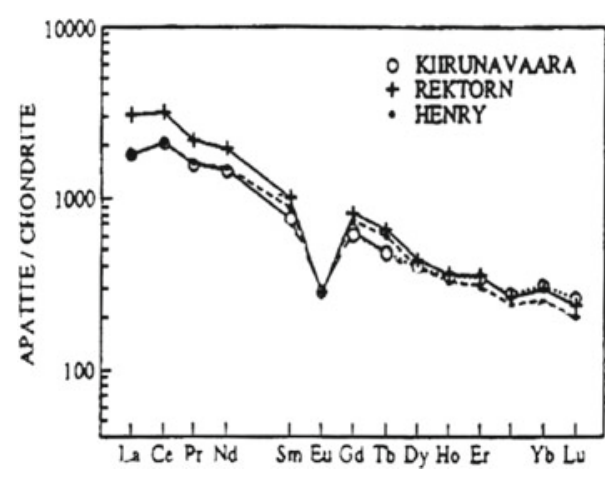

Figure 5. Chondrite-normalized REE patterns of apatites from Kiruna-type iron ores.

Chondrite normalized REE patterns of apatites (apatite crystals and phosphte ores), apatitebearing iron ores and magnetite ores with negligible amount of apatite or without apatite are similar in each iron-apatite ores of Posht-e-Badam Block (figure 4), however with a varying content of REE (very high in apatite crystals, high in apatitebearing iron ores and low in iron ores). Commonly, all phases are LREE-enriched and show negative Eu anomalies (iron ores in Lakeh Siah deposit indicate nearly flat REE patterns). These similar REE patterns indicate that these units have a common origin.

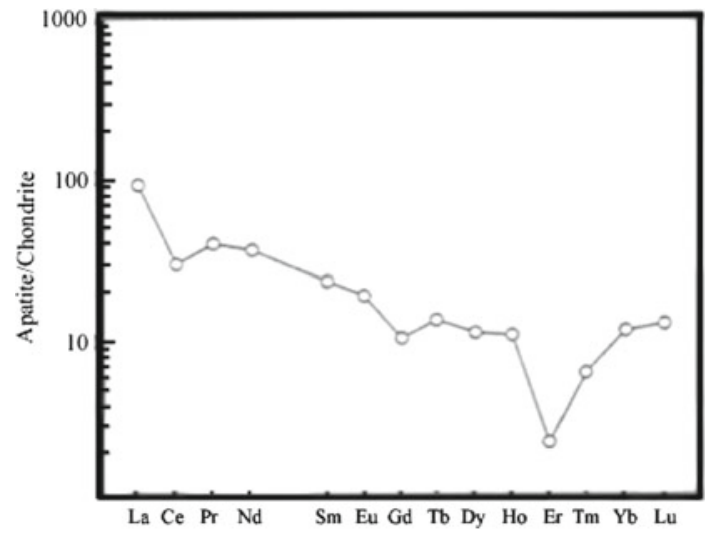

Figure 6. Chondrite-normalized REE pattern for apatites from phosphorites (Frietsch and Perdahl 1995).

Iron ores of Lakeh Siah deposit indicate flat REE patterns with a weak LREE/HREE fractionation (figure 4). This can be related to presence of pyroxene minerals (altered to tremolite-actinolite) together with magnetite. Moreover, a strong LREE/HREE fractionation in apatites can lead to HREE enrichment in the iron ore.

Most of the iron-apatite ores of Pasht-e-Badam Bolck (Central Iran) have similar patterns too (figure 4), which in turn show a genetic relation for these deposits. Samani (1999) believed that 

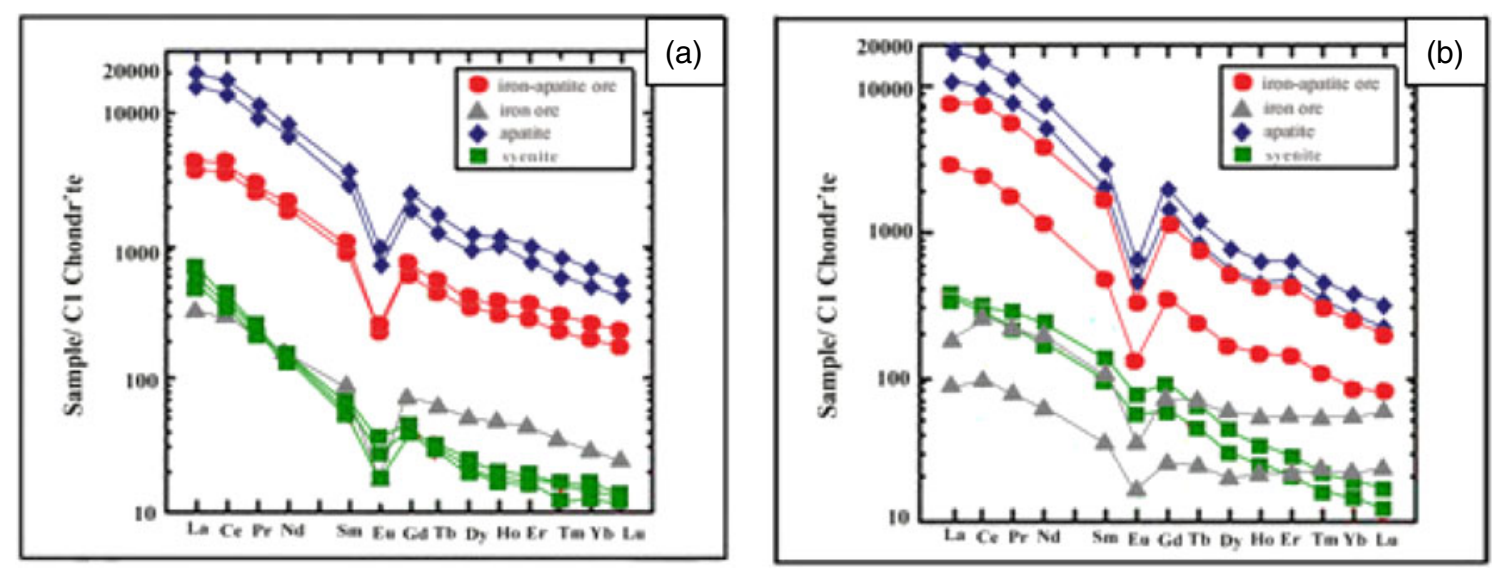

Figure 7. Chondrite-normalized REE pattern for apatites, apatite-bearing iron ores, iron ores and syenitic and gabbroic intrusions adjacent to them from Posht-e-Badam Block iron-apatite ores (a: north Esfordi, b: Lakeh-Siah).

high LREE content is the result of mantle metasomatism and enrichment of these elements in fluids originating from mantle that caused regional metasomatism.

The REE geochemistry of the apatites from the Posht-e-Badam Block is not only similar to other global apatite-magnetite ores, including those of Kiruna in Sweden, but also in part to both nelsonites and to the carbonatite association. However, they differ fundamentally from the sedimentary phosphorites, thus excluding a marine source.

Some of the researchers believed that ironapatite ores of Posht-e-Badam Block have genetic relation with alkaline intrusions that took place nearby (Williams and Houshmand Zadeh 1966; Daliran 1990; Förster and Jafarzadeh 1994; Darvish Zadeh and Al-e-Taha 1996; Samani 1999; Moore and Modaberi 2003; Jami 2005; Daliran and Stosch 2005). In this part of the paper, we are going to compare the REE patterns of syenitic and gabbroic intrusions located near the Esfordi and Lakeh Siah deposits with patterns of the iron-apatite ores.

Comparison of chondrite-normalized REE patterns of apatites, apatite-bearing iron ores and iron ores in the Esfordi and Lakeh-Siah deposits with those of syenitic and gabbroic intrusion located near them indicate very similar patterns (enrichment in LREE, a strong LREE/HREE fractionation and negative Eu anomalies) (figure 7). These similar patterns demonstrate that the mentioned syenitic and gabbroic intrusions and iron-apatite ores originated from a common magmatic source.

\section{Ore genesis}

Origin of the iron-apatite deposits of the Poshte-Badam Block, similar to their counterparts of the Kiruna-type systems, is controversial. The
Posht-e-Badam Block deposits had been considered as result of liquid immiscibility and injection or extrusion of ore magmas originated from alkaline/carbonatitic magmas, for many years (Samani 1988; Förster and Jafarzadeh 1994; Darvish Zadeh and Al-e-Taha 1996; Daliran and Stosch 2005). Samani (1988) reported field observations of carbonatite (?) dykes in some locations at the Bafq and Saghand areas.

Different tectonomagmatic settings have been proposed for the magmatic events associated with the iron-apatite mineralization in Central Iran. Extensional tectonic setting with the formation of an aborted rift that was originally introduced by Haghipour (1975), was further supported by Darvish Zadeh and Al-e-Taha (1996), Samani (1999) and Daliran (1990, 2002). Darvish Zadeh and Al-e-Taha (1996) believed that mineralization in this area is related with a high volcanism rifting structure (HVRS). Ramazani and Tucker (2003) describe the magmatic event of Bafq region to the arc-related calc alkaline magmatism of a Neoprotrozoic-Early Cambrian orogeny along the Proto-Tethyan margin of the Gondwana super-continent.

Daliran and Stosch (2005) believe that Posht-eBadam Block phosphate-REE deposits most likely were formed from sulphur-poor fluid source that was enriched in $\mathrm{Fe}, \mathrm{P}$ and REE. The source of these fluids may be linked to mantle degassing or to carbonatite magmas as is suggested by Samani (1998). Hauck (1990) states that alkaline magma is the ultimate source of iron-rich melts, which he suggests to have been derived from it by liquid immiscibility.

Moore and Modaberi (2003) describe at least two generations of apatite within the Choghart deposit. The first, which is contemporaneous with the main phase of iron oxide formation, displays 
euhedral crystals ranging in size from a few millimeters to a few centimeters in diameter. It is intimately intergrown with magnetite. The second generation occurs as subhedral to anhedral crystals in lenses, dikes, and veinlets of varying size and thickness, which cut the magnetite-apatite ore. Moreover, Jami (2005) reported four generations for apatite crystals based on mesoscopic and microscopic observations. The early stage is a LREE-rich apatite that occurs within the massive magnetite ore. The other generations are associated with hematite, actinolite, quartz-carbonate \pm REE and carbonate-quartz-actinolite-chloriteepidote \pm bastnaesite \pm synchesite vein and veinlets extending into the host rocks and magnetite ore body.

The field relationships and the overall geological evidence at the Posht-e-Badam Block iron-apatite deposits indicate that the rhyolitic to syenitic and gabbroic host rocks are the products of intracratonic plutonism and a tensional geological setting (rifting) were roughly synchronous and coeval with mineralization.

Presence of vesicular magnetite lava flows, sills, dikes and magnetite-bearing pyroclastic rocks at iron-apatite deposits of Posht-e-Badam Block is reported by some researchers (Förster and Borumandi 1971; Jafarzadeh 1981; Förster and Jafarzadeh 1984; Daliran 1990; Jafarzadeh 1994; Moore and Modaberi 2003; Jami 2005; Stosch et al. 2011). These evidences are suggested to be diagnostic of a magmatic origin. Also, geochemical evidences in these deposits (e.g., REE patterns; figure 4) indicate magmatic origin for them.

Pre-requisite for the formation of the Central Iran iron-apatite ores is an association with alkaline to sub-alkaline magmatic rocks in combination with proximity to large fault systems and an older basement. A probable source for this large-scale ore forming process was partial melting of mantle rocks.

The iron-apatite ores of Posht-e-Badam Block were probably formed by magmatic differentiation of an alkaline magma rich in $\mathrm{Fe}$ and incompotible elements such as P, REE, Th, U, F and $\mathrm{Cl}$ that was derived by partial melting of upper mantle. Deep seated faults caused transfering of parent magma and replacement in the upper parts of the crust. In this magma reservoir, the high phosphorous and alkali content probably led to the formation of a $\mathrm{Fe}-\mathrm{F}, \mathrm{CO}_{2}-\mathrm{H}_{2} \mathrm{O}-\mathrm{P}-\mathrm{Na}$ dominated immiscible melt which separated from a silica-rich melt. The high phosphorous content and the so-called alkali-iron effect (Guilbert and Park 1997) fluxed the immiscible melt and kept iron in solution at temperatures significantly lower than the melting point of magnetite at rather shallow depth (Moore and Modaberi 2003). The role of other volatile constituents such as $\mathrm{CO}_{2}$ and $\mathrm{F}$ is also important in this process (Weidner 1982). The presence of fluor-apatite and hydrous minerals (amphiboles) also suggests high $\mathrm{F}$ and $\mathrm{H}_{2} \mathrm{O}$ content. Both experimental and theoretical analyses of the behaviour of volatile-rich magma systems stress the important role liquid immiscibility may play (Kolker 1982). In some places, immicible portions of phosphates, oxides and silicates can be seen within another portion. It means that segregation of the magma were done within the crustal depth and wasn't complete. Silicate portion formed syenitic and gabbroic intrusions and oxide-phosphate melt ascent to upper parts.

The breakdown of this late immiscible phase has resulted in the formation of magnetite-apatite melt, which behaved intrusively at Choghart and similar deposits, and probably extrusively in occurrences such as Chador Malu and Lakeh Siah in the Posht-e-Badam Metalogenic Block. The intrusion or extrusion of the separated iron-oxide melt depends upon depth of separation, volatile content of iron-rich melt, and finally presence or absence of favourable tectonic and structural conditions.

Most of the high concentration of REEs was probably partitioned as F-REE complexes in the fluorine-dominated fluid generated during volatile exsolution. The majority of the REEs are contained in apatite and REE-bearing microscopic solid inclusions such as monazite and xenotime in apatite (Jami 2005; Torab 2010; Stosch et al. 2011).

Presence of volatiles led to the alteration, breciation and metasomatism of country rocks. In this stage, iron ores formed with some amounts of apatite. Crystallization of magnetite caused increasing of pressure in the fluid phase rich in volatiles and incompatible elements (such as $\mathrm{P}$, REE, Th, U, F and $\mathrm{Cl}$ ). Finally, this fluid invaded the iron ores and country rocks and formed the phosphatic zone or iron-apatite zones around or within the iron ores. It can be seen as phosphatic veins and veinlets within the iron ores at Choghart, Esfordi, Gazestan and Lakeh Siah deposits (Moore and Modaberi 2003; Jami 2005).

Based on rare earth element distribution in apatites, liquid immiscibility is proposed as a process of primary ore generation in the ironapatite deposits of the Posht-e-Badam Block. However, textural evidence to support the hypothesis of liquid immiscibility is mostly destroyed by younger metasomatic/hydrothermal modifications and recrystallization.

\section{Conclusion}

The consistent spatial and temporal association of the iron-apatite ores within the narrow zone of 
Posht-e-Badam Block provides conclusive evidence of a common source of these ores. Iron-apatite ores from Posht-e-Badam Block (Central Iran) have comparable REE patterns that demonstrate a similar origin and processes in their genesis. The REE patterns of apatites in Central Iran iron ores show an affinity to alkaline to sub-alkaline magmas and rifting environment (SSE-NNW fault lines). A probable source for this large-scale ore forming process was partial melting of mantle rocks. The ores were formed during magmatism as immiscible liquids which separated from strongly differentiated magmas, aided by large volatile and alkali elements content.

In summary, it may be concluded that following the establishment of late Proterozoic extensional tectonic regime in the Posht-e-Badam Block and the onset of alkaline magmatism, iron oxide mineralization occurred at this region. In view of the enormous size of the ore body, the large volume of melt or high temperature hydrothermal fluid needed for the formation of these deposits, and the conflicting evidence for and against liquid immiscibility or hydrothermal origin, neither of the two hypotheses alone can be held responsible for the formation of them. It is suggested here that the separation of an iron oxide melt and the ensuing hydrothermal processes dominated by alkali metasomatism were both involved to different degrees in the formation of Posht-e-Badam Block iron-apatite deposits.

\section{Acknowledgements}

This study was financially by the Geological Survey of Iran (GSI). The authors would like to thank Eng. Korehi, Head of Geological Survey of Iran and Dr Mehrpartou, the exploration assistant of Geological Survey of Iran for the help to analyse samples in ALS-Chemex Laboratory.

\section{References}

Abedian N 1983 Detailed exploration on Esfordi phosphate deposit; Geological Survey of Iran, 68p (in Persian).

Altschuler Z S 1980 The geochemistry of trace elements in marine phosphorites, 1: Characteristic, abundance and enrichment; Soc. Eco. Paleontol. Mineralogist, Spec. Publ. 29 19-30.

Aral H 1986 The geology, geochemistry and magnetiteapatite mineralization of the Avnik area, Genc-Bingol, SE Turkey; Geol. Ultraiectina. Meded. Inst. Aardwetenschappen Rikjkuniversiteit Utrecht 44 245p.

Barton M D and Johnson D A 1996 Evaporitic-source model for igneous-related $\mathrm{Fe}$ oxide- $(\mathrm{REE}-\mathrm{Cu}-\mathrm{Au}-\mathrm{U})$ mineralization; Geology 24 259-262.

Bergman S, Kubler L and Martinsson O 2001 Description of regional geological and geophysical maps of northern
Norrbotten County (east of the Caledonian orogen); Sver. Geol. Unders 56 110p.

Bonyadi Z, Mehrabi B, Davidson J, Meffre S and Ghazban F 2010 Apatite chemistry and its application to the hydrothermal evolution of the Se-Chahun magnetiteapatite deposit; The 1st International Applied Geological Congress, Islamic Azad University, Mashhad, Iran, pp. 2103-2106.

Borumandi H 1973 Petrographische und lagerstatten kundliche untersuchungen der Esfordi-formation zwischen Mishdovan und Kushk bei Bafg (Zentral Iran); Diss. RWTH Aachen, 174p.

Broman C, Nystrom J, Henriquez F and Elfman M 1999 Fluid inclusions in magnetite-apatite ore from a cooling magmatic system at El Laco, Chile; GFF 121 253-267.

Brown G M and Peckett A 1977 Fluor-apatite from the Skeargaard intrusion, east Greenland; Mineral. Mag. 41 227-232.

Daliran F 1990 The magnetite-apatite deposit of Mishdovan, east central Iran. An alkali rhyolite hosted 'Kirunatype' occurrence in the infracambrian Bafg metallotect; Ph.D. thesis, Univ. of Heidelberg, Geowiss. Abhandl. 37 248p.

Daliran F 1999 REE geochemistry of Bafg apatites: Implication for the genesis of Kiruna-type iron ores; In: Mineral deposits: Processes to processing (eds) Stanley et al., Balkema, Rotterdam, pp. 631-634.

Daliran F 2002 Kiruna-type iron oxide-apatite ores and apatitites of Bafq district, Iran, with an emphasis on the REE geochemistry of their apatites; In: Hydrothermal iron oxide copper-gold and related deposits (ed.) Porter T M, PGC Publishing, Linden Park, South Australia, pp. 303-320.

Daliran F and Stosch H G 2005 Geology and metallogenesis of the phosphate and rare earth element resources of the Bafq iron ore district, Central Iran; 20th World Mining Congress, 7-11 November Tehran, Iran.

Daliran F, Stosch H G and Williams P 2009 A review of the Early Cambrian magmatic and metasomatic events and their bearing on the genesis of the Fe oxide-REE-apatite deposits (IOA) of the Bafq District, Iran; In: Smart science for exploration and mining: Proceedings of the 10th Biennial SGA Meeting (eds) Williams et al., Townsville, Australia, 17-20 August, 2009.

Daliran F, Stosch H G, Williams P, Jamali H and Dorri M B 2010 Early Cambrian iron oxide-apatite-REE (U) deposits of the Bafq District, east-central Iran; In: Exploring for iron oxide copper-gold deposits: Canada and Global analogues (eds) Corriveau L and Mumin H, Geol. Assoc. Canada, Short Course Notes 20, pp. 143-155.

Darvish Zadeh A 1982 Investigation of the phosphate in Bafq (Esfordi); J. Sci., University of Tehran 28(1) 2-24 (in Persian).

Darvish Zadeh A and Al-e-Taha B 1996 Late Precambrian magmatism and tectono-magmatism in Central Iran; $J$. Sci., University of Tehran 22(1) 57-78 (in Persian).

Förster H J and Borumandi H 1971 Neo-Precambrian magnetite lava and magnetite tuffs from the Central Iran; Naturwissenschaften $\mathbf{5 8} 524$.

Förster H J and Jafarzadeh A 1984 The Bafq mining district in central Iran: A highly mineralized Infracambrian volcanic field; Econ. Geol. 89(8) 1697-1721.

Förster H J and Jafarzadeh A 1994 The Chador Malu iron ore deposit, Bafq district, Central Iran, magnetite filled pipes; Neues. Jahb. Palaont. Abh. 168 524-534.

Frietsch R and Perdahl J A 1995 Rare earth elements in apatite and magnetite in Kiruna-type iron ores and some other iron types; Ore Geol. Rev. 9 489-510. 
Frutos J, Oyarzun J, Shiga Y and Alfaro G 1990 The El Laco magnetite flow deposits, northern Chile: An up-todate review and new data; In: Strata bound ore deposits in the Andes (eds) Fontbote L et al., Soc. Miner. Dep., Spec. Publ. 8 681-690.

Guilbert J M and Park C F 1997 The geology of ore deposits; WH Freeman and Company, 958p.

Haghipour A 1964 Iron ore deposits in Central Iran, in relation to structural geology and metamorphism, scapolitization and albitization; J. Iranian Petroleum Institute $\mathbf{7 6}$ $1-9$.

Haghipour A 1975 Etude geologique de la region de Biabanak-Bafg (Iran central): Petrography et tectonique du scale Precambrian et de sa couverture, Ph.D. thesis, Grenoble University, 403p.

Haghipour A and Pelissier G 1977a Geological map of the Biabanak-Bafq area; Geological Survey of Iran.

Haghipour A and Pelissier G 1977b Geology of the Saghand sector geological map of the Biabanak-Bafq area; In: Explanatory text of the Ardakan quadrangle map (eds) Haghipour A, Valeh N, Pelissier G and Davoud Zadeh M, H8, Geological Survey of Iran, pp. 10-68.

Harlov D E, Anderson U B, Förster H J, Nystrom J O, Dulski $\mathrm{P}$ and Broman C 2002 Apatite-monazite relation in the Kirunavaara magnetite-apatite ore, northern Sweden; Chem. Geol. 191 47-72.

Hauck S A 1990 Petrogenesis and tectonic setting of the middle Proterozoic iron oxide-rich ore deposits: An ore deposit model for Olympic Dam-type mineralization; In: The Mid-continent: Permissive Terrain for an Olympic Dam Deposit? (eds) Pratt W P and Sims P K, USGS Bull. 1932 4-39.

Helvaci C 1984 Apatite-rich iron deposits of Avnik (Bingol) region, SE Turkey; Eco. Geol. 79 371-406.

Hughes J M, Cameron M and Mariano A N 1991 Rare earth element ordering and structural variations in natural rare earth bearing apatites; Am. Mineral. 76 1165-1173.

Jafarzadeh A 1981 Die magnetite rzlagerstatte Chador Malu in zentral Iran und ihre exploration; Ph.D. thesis, Aachen University, $152 \mathrm{p}$.

Jami M 2005 Geology, geochemistry and evolution of the Esfordi phosphate-iron deposit, Bafq area, Central Iran; Unpublished Ph.D. thesis, University of South Wales, 403p.

Kolker A 1982 Mineralogy and geochemistry of Fe-Ti oxide and apatite (nelsonite) deposits and evolution of the liquid immiscibility hypothesis; Eco. Geol. 77 11461158.

Kryvdik St and Mykhaylov V 2001 The potential of the rare earth mineralization of Islamic Republic Iran; National Academy of Science of Ukraine, 48p.

Laajoki J M 1975 Rare earth elements in Precambrian iron formations in Vayrylankyla, south Puolanka area, Finland; Bull. Geol. Soc. Finland 47 93-107.

Mokhtari M A A and Emami M H 2008 REE patterns and REE mineralization in apatite-magnetite deposits of Bafq-Saghand District (Central Iran); Geosciences, Scientific Quart. J., Spec. Issue 17(1) 161-168.

Momen Zadeh M 1978 Fe, Zn-Pb resources in the Infracambrian meta-volcano-sedimentary rocks of Posht-e-BadamSaghand-Bafq area, a genetic interpretation; Geological Survey of Iran, 21p (in Persian).

Momen Zadeh M 1982 Syngenetic ore deposits: A provisional classification and the main syngenetic metallogenetic stages in Iran; Geological Survey of Iran, 61p (in Persian).

Momen Zadeh M 1986 Submarine volcanism as the only source for major stratiform syngenetic-synsedimentary ores; Geological Survey of Iran, 19p (in Persian).
Moore F and Modaberi S 2003 Origin of the Choghart iron oxide deposit, Bafq mining district, Central Iran: New isotopic and geochemical evidences; J. Sci., University of Tehran 14(3) 259-268.

Naslund H R, Aguirre R, Dobbs F M, Henriquez F J and Nystrom J O 2000 The origin, emplacement and eruption of ore magmas; IX Congreso Geologico Chileno Actas, Chile 2 135-139.

NISCO 1971 Report on the results of geological-geophysical prospecting for iron ores in the Bafq-Saghand area; Unpubl. Rept., National Iranian Steel Corporation, $195 \mathrm{p}$.

NISCO 1974 Material of geological prospecting work in the Bafq iron ore region for elaboration of a technical and economic report on iron ore prevision of the Esfahan steel plant in view of production expansion; Unpubl. Rept., National Iranian Steel Corporation, 81p.

NISCO 1975 The results of the geological prospecting at the Chador Malu deposit; Unpubl Rept., National Iranian Steel Corporation, $57 \mathrm{p}$.

NISCO 1979a Brief account on the Bafq iron ore region of Central Iran; Unpubl. Rept., National Iranian Steel Corporation, 149p.

NISCO 1979b Detailed geological exploration carried out at the Chador Malu deposit; Unpubl. Rept., National Iranian Steel Corporation, 256p.

NISCO 1980 Result of search and valuation works at magnetic anomalies of the Bafq iron ore region during 19761979; Unpubl. Rept., National Iranian Steel Corporation, 260p.

Parak T 1975 Kiruna iron ores are not 'intrusive--magmatic ores of the Kiruna-type'; Eco. Geol. 70 1242-1258.

Parak T 1985 Phosphorus in different types of ores, sulfides in the iron deposits and the type and origin of ores at Kiruna; Eco. Geol. 80 646-665.

Paster T P, Schauwecker D S and Haskin L A 1974 The behavior of some trace elements during the solidification of the Skaergaard layered series; Geochim. Cosmochim. Acta 38 1549-1577.

Philpotts A R 1967 Origin of certain iron-titanium oxide and apatite rocks; Eco. Geol. 62 303-315.

Piccoli P M and Candela P A 2002 Apatite in igneous systems; In: Phosphates (reviews in mineralogy and geochemistry) (eds) Kohn M J, Rakovan J and Hughes J M, Miner. Soc. America and Geochem. Soc., Washington, 48 255-292.

Rahmani Sh and Mokhtari M A A 2002 Exploration of metallic rare elements; Geological Survey of Iran, 365p (in Persian).

Ramazani J and Tucker R D 2003 The Saghand region, Central Iran: $\mathrm{U}-\mathrm{Pb}$ geochronology, petrogenesis and implications for Gondwana tectonics; American J. Sci. 303 $622-665$.

Samani B 1988 Metallogeny of the Precambrian in Iran; Precamb. Res. 39 85-106.

Samani B and Babakhani A 1990 Geological evolution of the Bafq-Saghand region and metallogenic model for the iron-apatite and radioactive deposits; 9th Symposium on Geosciences, pp. 24-25 (in Persian).

Samani B 1993 Saghand formation, a riftogenic unit of upper Precambrian in Central Iran; Geosciences, Geological Survey of Iran 6 32-45 (in Persian).

Samani B 1998 Precambrian metallogeny in Central Iran; Scientific Bulletin of the Atomic Energy Organization of Iran 17 1-16 (in Persian).

Samani B 1999 Rare earth element mineralization in Precambrian of Central Iran; Scientific Bullettin of the Atomic Energy Organization of Iran 20 15-31 (in Persian). 
Shamsi Pour R, Khakzad A, Rasa I and Vosoughi Abedini M 2008 Mineralogy and fluid inclusion studies of Chador Malu iron ore deposit, Bafq, Central Iran; Res. J. University of Isfahan 29(3) 129-144 (in Persian).

Stöcklin J 1968 Structural history and tectonics of Iran: A review; American Association of Petrol. Geol. Bull. 52 1229-1258.

Stosch H G, Romer R L, Daliran F and Rhede D 2011 Uranium-lead ages apatite from iron oxide ores of the Bafq District, east-central Iran; Mineralium Deposita 46 9-21. Taghizadeh N 1976 The iron ore deposits of Iran; In: The iron ore deposit of Europe and adjacent areas; explanatory notes to the international map of the iron ore deposits of Europe (ed.) Zitzmann A, Bundesanstalt fur Geowissenschaften und Rohstoffe, Hannover, pp. 199202.

Taylor R P and McLennan S M 1985 The continental crust: Its composition and evolution; Blackwell, Oxford, $312 \mathrm{p}$.

Torab F M 2010 Geochemistry and radio-isotope studies on the iron-apatite ores in Bafq metalogenic zone for determination of apatite origin; Iranian J. Crystallogr. Mineral. 18(3) 409-418 (in Persian).

Weidner R J 1982 Iron oxide magmas in the system F-C-O; Canadian Mineral. 20 555-666.

Williams G J and Houshmand Zadeh A 1966 A petrological and genetic study of the Choghart iron ore body and the surrounding rocks; Geological Survey of Iran, 18p. 